Rubasinghe, K., Disaratne, V. and Mahinkanda, M.M.M.P., 2019. Suitability of traditional procurement system for green buildings in Sri Lanka. In: Sandanayake, Y.G., Gunatilake, S. and Waidyasekara, A. (eds). Proceedings of the $8^{\text {th }}$ World Construction Symposium, Colombo, Sri Lanka, 8-10 November 2019, pp. 547 -555. DOI: doi.org/10.31705/WCS.2019.54. Available at: https://2019.ciobwcs.com/papers

\title{
SUITABILITY OF TRADITIONAL PROCUREMENT SYSTEM FOR GREEN BUILDINGS IN SRI LANKA
}

\author{
Kasuni Rubasinghe ${ }^{1}$, Vijitha Disaratne ${ }^{2}$ and M.M.M.P. Mahinkanda ${ }^{3}$
}

\begin{abstract}
Green building construction is a momentous process of sustainability. It signifies the environmental credibility of sustainable. Further, it addresses the energy performance, overall cost of the construction product and conservation of natural resources. Therefore, green building concept has foremost influence on construction industry. Yet, it has core barriers in cost, knowledge, risk and government factors when involve the green construction to construction industry. Hence, procurement system can involve in reducing those barriers. Green procurement signifies both product and process of the construction. Concerning the process base, there are different procurement systems involved in different countries which depend on internal and external factors. There is high involvement in design and build procurement system worldwide which include Sri Lankan context as well. The status of applying traditional procurement system in green construction is significantly high even though it is not considered as highest. Therefore, it has high involvement on addressing the barriers through critical factors of traditional procurement system. It was carried out nine expert survey with qualitative analysis in order to identify involvement of traditional procurement system to green building construction. Accordingly, it focused on the critical factors of traditional procurement system specifically cost, time, complexity, client's involvement, project characteristics and technology. These success factors addressed the barriers which raised through high cost, lack of knowledge, risk and other influences of green building construction. Finally, this research subsidizes to knowledge, green procurement system provides the benefits to increment of green building construction in Sri Lanka.
\end{abstract}

Keywords: Green Building Construction; Green Procurement; Procurement; Sustainability; Traditional Procurement System.

\section{INTRODUCTION}

According to Low et al., (2014) "the greening buildings have become one of the most effective strategies for sustainable development"(Pg. 414). Author Liu et al., (2012) "Efforts on green buildings have generally focused on energy efficiency, conservation of natural resources, new environmentally friendly building materials and also revolutionary changes in concepts of design, procurement and management processes to bring about greater reduction in overall environmental impact of buildings" (p. 51).

Selecting a suitable procurement system is a major function that has to be adopted in building construction (Chan et al., 2001). Procurement has become important to a project

\footnotetext{
${ }^{1}$ Department of Building Economic, University of Moratuwa, Sri Lanka, Kasuni28@gmail.com

2 Department of Building Economic, University of Moratuwa, Sri Lanka, Vijithad@uom.lk

${ }^{3}$ Department of Building Economic, University of Moratuwa, Sri Lanka, mmahinkanda@uom.lk
} 
in overall quality in economics, social and environmental aspects (Oyegoke, et al., 2009). There are common factors which affect to procurement system such as economic, legal, political, technology, client resources, project characteristics, variation, cost issues and time (Davis, et al., 2008).

"Green procurement is the purchase of product or services which minimize or provide positive environmental impact." (Wong et al., 2016). Yet, this research identified the involvement of procurement systems to green building construction with emphasizing the status of traditional procurement system, addressing the barriers of green buildings construction and overcome them with success factors and identify the critical factors of traditional procurement systems which can address the barriers occur in green building implementation. According to literature findings, it is confirmed that many researchers have conducted research regarding green buildings and procurement, yet researches regarding green procurement system are done in less numbers. There are several researched has been carried out for overall green procurement system. Conversely, the depth study on traditional procurement system involvement on Green building has not been covered which identified as problem statement in this research. Hence, the aim of this research is to investigate the applicability of traditional procurement system to the procurement of green buildings in Sri Lanka.

\section{LITERATURE REVIEW}

\subsection{SUSTAINABLE CONSTRUCTION AND ENVIRONMENTAL SUSTAINABILITY}

Sustainable construction helps the building industry to achieve development by resolving the issues of environmental, cultural and socio-economic. In addition to that with proper management of all the features, the sustainable construction seeks to reduce the additional cost of all designing, constructing, operating and overall cost welfare (Shafii, et al., 2006). The environmental sustainability ensures that the environment and humans are interacting naturally (Bombugala and Atputharajah, 2010). The authors Hwang and Leong (2013) also proved the status by stating that "the term green building is defined as an environmentally sustainable building which is constructed with minimal environmental impacts" (p.312).

\subsection{GREEN BUILDING IN CONSTRUCTION}

According to Seyis and Ergen (2017) green building is high performance buildings that are designed and constructed in resource efficient manner to preserve energy, water, material and land through application environmental principals. It categorized under six (6) main parts as shown in Figure 1.

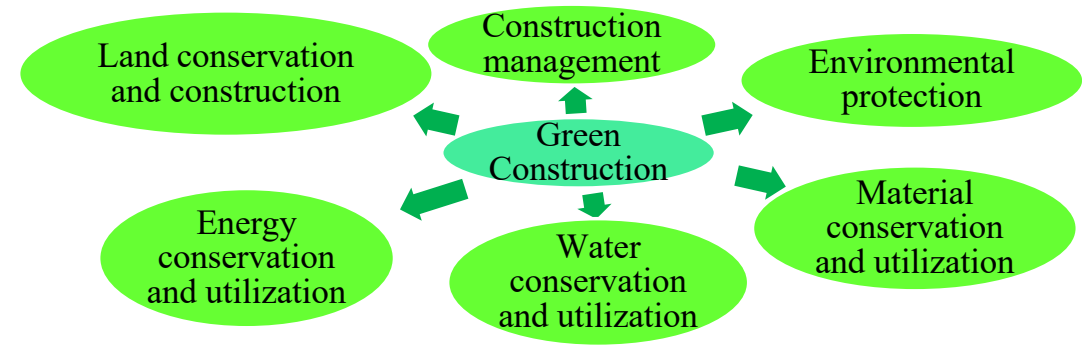

Figure 1: Green construction categorization (Source: Adapted from Shi, et al., 2013) 


\subsection{PraCtices in Green BUILdingS}

The employers make effort for pursuing the green building in order to enhance the building performance (Hettige, et al., 2016). Due to the significance of the green building, it has increased the popularity among architectural, engineering and construction industry in different countries as well (Li, et al., 2018).

\subsection{Motivating FACTORS OF AdOPTING Green BuILDINGS}

There are several benefits can be gain through green buildings which are also categorized as economic, social and environment benefits (Waidyasekara and Fernando, 2012). As examples lowering energy, water wastewater costs. As social example expand market for environmentally preferable and as for environmental negative impact and mitigate carbon emission (Thatcher and Milner, 2016).

\subsection{BARRIERS IN IMPLEMENTING GREEN BUILDING TECHNOLOGY}

There are several barriers identified when implementing green technology. As the main barriers which directly influence when implementing the green building technology there are six barriers identified as shown in Figure 2.

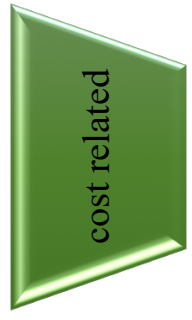

Figure 2: Barriers in implementing green building technology (Source: Adapted from Chan et al., 2018; Sim and Putuhena, 2015)

\subsection{PROCUREMENT IN CONSTRUCTION}

Procurement in construction is the process of contributing employers' satisfaction through the suitable process of designing and constructing. Rwelamila (2010) also defines procurement as distributing responsibilities among stakeholders and organization with defining relationship of project elements of construction project.

There are four (4) types of procurement system as in, separated, intergrated, management oriented and collaborative.

Table 1: Classification of types of procurement system

\begin{tabular}{lllll}
\hline Ref & \multicolumn{1}{c}{ Separated } & \multicolumn{1}{c}{ Integrated } & Management Oriented & Collaborative \\
\hline R1 & Traditional, Lump & Design and build (D\&B) & Design and manage & \\
& sum, Cost & Novation, Package deal// & Management contracting & - \\
& reimbursement & Turnkey & Construction management & \\
& Provisional & Contractors design and & & \\
& quantities & construct & & \\
R2 & Lump Sum & D\&B, Package Deal & Construction Management & Partnering \\
& Measure and Pay & Turnkey, Develop and & Management Contracting & Joint Ventures \\
& Prime cost & Construct & D\&M & Alliancing
\end{tabular}


Novated, Concession

Voluntary

Contracts

Arrangements

All-in contracts

R3 Design bid

D\&B, Design

Partnership

Design, Build and Manage

Partnering

build

Novation

Management contracting

Construction management

Building own operate

transfer

Sources: R1 - Love, et al. (1998); R2 - Shiyamini, et al. (2005); R3 - Vilasini, et al. (2011)

\subsection{Factors Affecting Selection of Procurement Systems to the CONSTRUCTION}

The selection of suitable procurement system is a significant process in both employer and project participant perspective as the selection can affect the project failure or success.

Table 2: Success factors for selecting a procurement system

\begin{tabular}{|c|c|}
\hline Reference & Factor \\
\hline $\begin{array}{l}\text { Mathonsi and Thwala, } \\
\text { (2012) }\end{array}$ & Client's requirement \\
\hline $\begin{array}{l}\text { Davis, et al., (2008); } \\
\text { Jefferies et al., (2002) }\end{array}$ & $\begin{array}{l}\text { Economical, Commercial, Technological, Political, Legal, } \\
\text { Social }\end{array}$ \\
\hline $\begin{array}{l}\text { Cheung, et al., (2010); } \\
\text { Davis, et al.,(2008) }\end{array}$ & $\begin{array}{l}\text { Resources, Project characteristics, Variations, Responsibility, } \\
\text { Authority }\end{array}$ \\
\hline Jefferies et al, (2002) & $\begin{array}{l}\text { Environmental impact, complexity, support, Selecting the right } \\
\text { project, Org. size-resource management ability, trust, } \\
\text { Community support, Financial capability }\end{array}$ \\
\hline Chan et al., (2001) & Constrains imposed by End-Users \\
\hline
\end{tabular}

\subsection{Procurement Systems in Green BuILdings}

Green building procurement is procuring concerning environmental impact of the building (Bohari et al., 2017). As per the Stener (2002) the green building procurement system is also defined as a technical implication, construction procedure which involves the procurement aspect.

\subsection{Adoption OF Green Procurement to Buildings}

Green procurement is identifying, integrating and implementing of green practices in the procurement procedure which is a complex process and commences at the planning stage and continues to contract execution (Bohari et al., 2017). A product base is concerned about the standard and the environmental friendliness of materials and products.

When implementing any procurement system such as conventional, design and building or partnering to green buildings there is an desired environmental criteria of the product and services as guideline for the design team and construction team (Bohari et al., 2017). 


\subsection{APPlication of Procurement System to Green Buildings}

Ahn, et al., (2016) explained that the green building constructions are actions of multidisciplinary team. Further, as stated by Ahn, et al., (2016) South korea has used the design bid build system with intergrated construction process which is considered as the most popular method in South Korea. According to Rose (2014), most suitable procurement system was identified as collaborative system and D\&B and also the auther further stated that least suitable system as traditional procurement system. Therefore, according to unique features of the countries they have identified different procurement systems as suitable procurement system.

\section{RESEARCH METHODOLOGY}

The data collection commenced with a pilot survey and un-structured interviews of experts. Qualitative analysis was carried out to analyze data. Due to lack of experts who have involved in procurement systems and green building construction at the same time qualitative approach is selected. It was preceded with interviewing experts gathered with one pilot surveying which was carried out to clarify the research area, the interview guideline and also to verify literature findings and to clarify debatable points in literature and 9 expert interviews who have involved in different project with playing different roles such as consultant, contractor and site engineer. Content analysis method was used to analyse the data with the method of N-vivo (2012) software. Finally, after whole process is completed the expectation of the researcher is to identify all objectives and answer the research problem.

\section{RESEARCH ANALYSIS AND FINDINGS}

\subsection{PILOT SURVEY AND EXPERT SURVEY}

Through the survey, barriers that influence to green building construction which have integrated to procurement system were identified and also identified the client's perspective regarding the selection of a suitable procurement system to the relevant project. The concerns and facts of the respondents were also emphasized through this survey.

Main concerns of this analysis were factors affecting the selection of a suitable procurement system and the barriers that has to overcome in selecting green buildings.

\subsection{Status of Procurement Systems in Green BuILdingS}

It was recognized that the awareness of other procurement systems to green buildings such as management oriented and collaborative systems are less than traditional and D\&B procurement systems (see Figure 3). Based on the results, $50 \%$ of projects are conducted by $\mathrm{D} \& \mathrm{~B}$ procurement system. Thus, it clarifies that the most of the green building constructions are proceeded through D\&B procurement system. Yet, as the traditional procurement system provides $43 \%$, it can be considered that traditional procurement system is also used reasonably. 


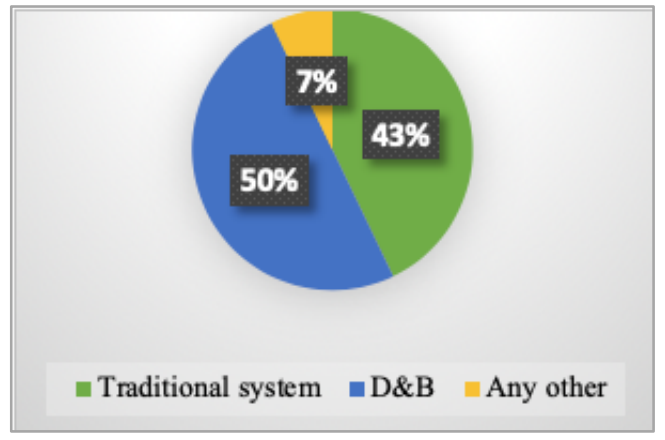

Figure 3: Selection of procurement systems of green buildings

\subsection{BARRIERS IMPLEMENTING GREEN BUILDING TECHNOLOGY}

According to respondents, green buildings have a major impact on global changes in sustainability. Also, most of the respondents agreed that economic features have a higher impact for global change in sustainability than the social impact. There are seven barriers as identified as Cost, Human, Market, Government involvement, Risk, Knowledge and Interest of People and they have relationship with each other (refer Figure 4).

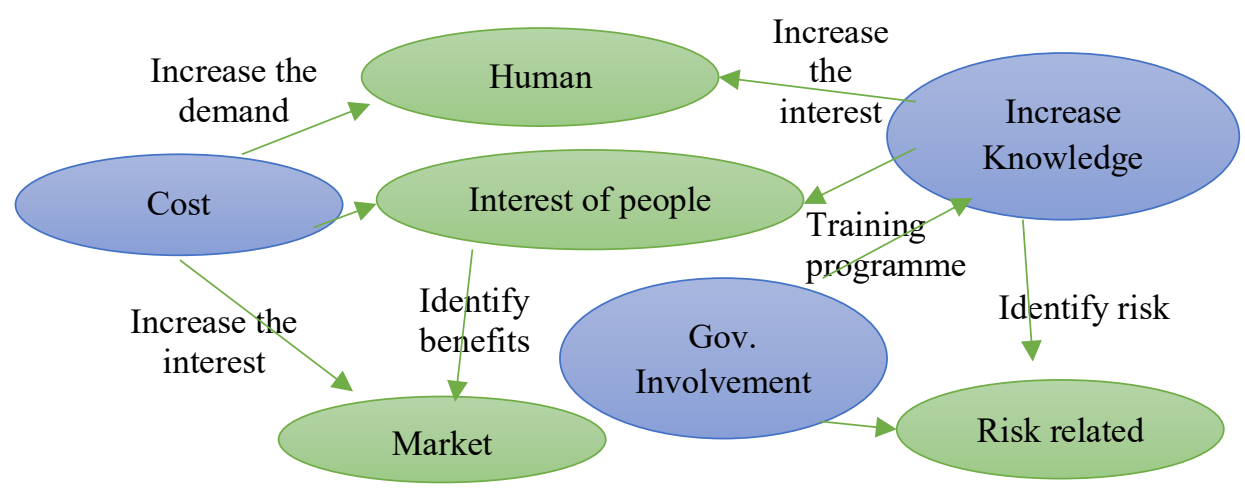

Figure 4: Impact of barriers and mitigation of barriers

Green building construction is a complex construction system. With identified barriers it gets more complicated. Hence, these barriers should be addressed to reduce the complexity of the project itself. As shown in Figure 4 cost reduction helps to increase the interest of people and also the interest of the market. It helps to increase the demand of human as well. With the increasing knowledge, people will aware of the risk beforehand. Further, it helps to identify the benefits resulting interest among the people. Also, human related barriers will be reduced with the people's interest. With the government involvement, it increases the knowledge due to the implementation of programmes and reduce the risk.

Those identified solutions are general solutions which can be addressed to mitigate the barriers. Other than above identified solutions, the barriers can be addresses in construction aspect as well.

\subsection{Selection of Traditional Procurement System (TPS)}

Selecting a suitable procurement system has a major impact on the development of green building construction. It can be changed due to several reasons such as cost, time, project characteristics and client's requirements as identified factors. 
Selection of a procurement system depends on the current status, internal factors and external factors as identified in the literature review. There are seven critical factors of traditional procurement system which identified through success factors of procurement system as in, Cost, time, complexity, client involvement, project characteristics, technology and variation.

There is high involvement of cost, client involvement and project characteristics in selecting traditional procurement system. So, with analyzing responses it further identified that the positive impact of those identified factors when implementing traditional procurement system.

Table 3: Impact of the factors to select traditional procurement system as suitable system to green buildings

\begin{tabular}{|c|c|c|}
\hline Factor affecting TPS & Level of Impact & Reason for the impact \\
\hline Cost & Highest impact & $\begin{array}{l}\text { Due to less variation, Prior } \\
\text { identification of the cost }\end{array}$ \\
\hline Time & Impact & Due to less variation \\
\hline Complexity & Higher impact & $\begin{array}{l}\text { Work commence with client's } \\
\text { involvement }\end{array}$ \\
\hline Client involvement & Highest impact & Direct involvement \\
\hline Project characteristics & Higher impact & Follow client's scope \\
\hline Technology & Impact & Reduced unnecessary cost \\
\hline
\end{tabular}

Consequently, it identified that most of factors have high impact when selecting a traditional procurement system as suitable system. There is less impact in time and technology compared to other factors. Yet, through the respondents' opinions it verified that how those factors affect to selection and what are the benefits that can be gain through selection of traditional procurement system. Therefore, through critical factors of traditional procurement system it can address the barriers of green building construction and helps to increase the green construction in long run.

Considering barriers identified and factors affecting to TPS, the relationship can be identified as illustrated in Figure 5. Figure 5 illustrates what factors address the barriers. According to that there can be one factor that can address several barriers.

\section{CONCLUSIONS}

Development of construction industry has become obliging with involvement of sustainability. In Sri Lankan construction industry, there is less increment of green building construction due to numerous reasons highlighting the lack of knowledge on green aspects. There are different types of procurement systems which are involved in construction industry. The proper selection can address the client's requirement, financial issues, management risks and procedure of the work. Implication of suitable procurement system influenced to reduce the complexity of the green building construction. This research is based on mapping above two concepts of green construction and procurement systems. Therefore, with providing the solution to research aim, which is investigating applicability of traditional procurement system to the procurement of green building in Sri Lanka was established alone with identifying objectives. 


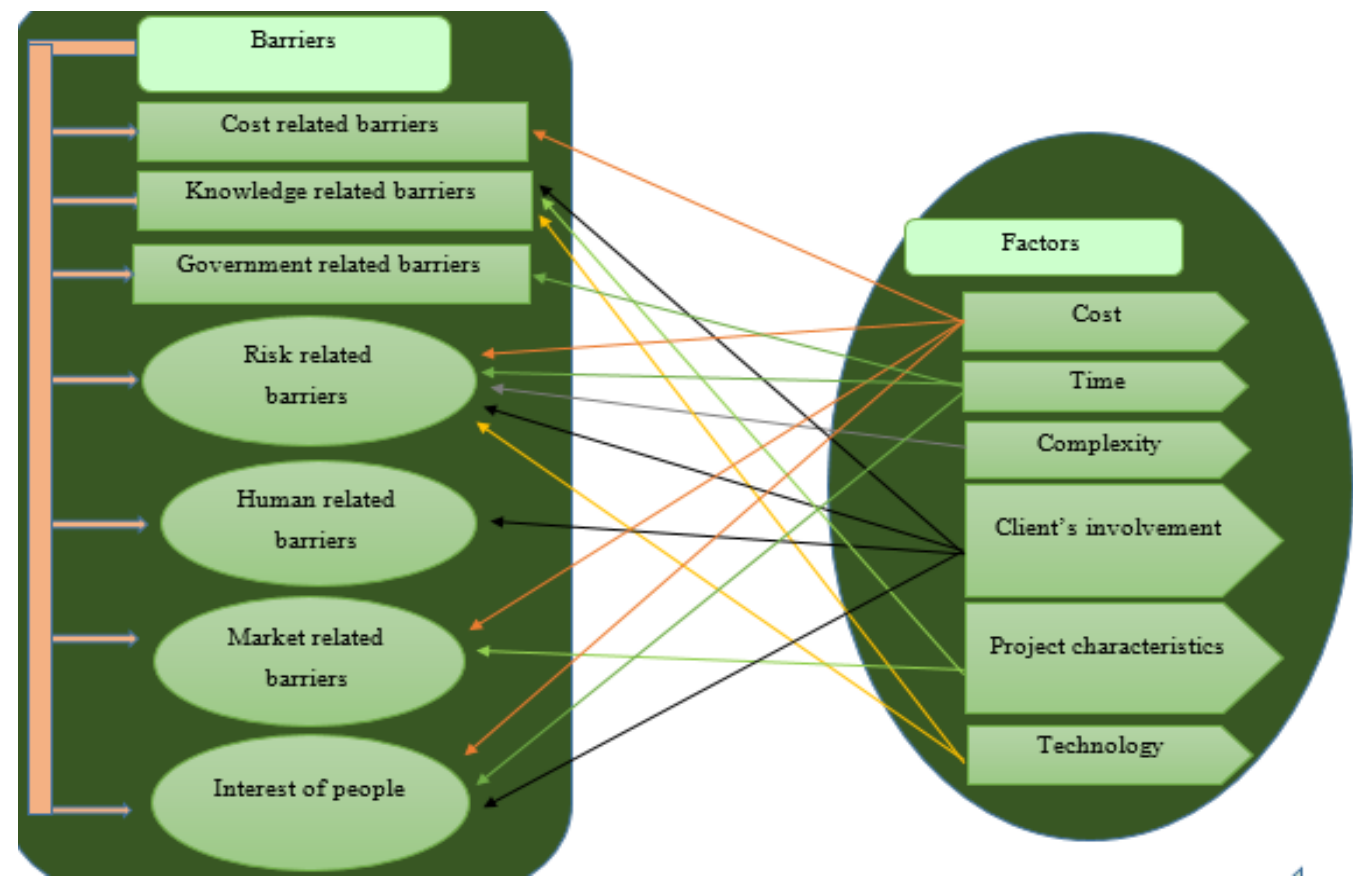

Figure 5: Address the barriers through critical factors

As main identification the application of procurement system in green building construction is analysed. As a result, the status of applying traditional procurement system to Sri Lankan context has identified as second highest implication in Sri Lanka. Then identified how the barriers can be addressed through procurement system and finally involvement of traditional procurement system with critical factors to address the barriers. It identified there is significant involvement in traditional procurement system and it can successfully address the barriers of green building construction. Accordingly, this research has addressed the research problem and contributed to knowledge on increasing the green building construction through procurement systems.

\section{REFERENCES}

Ahn, Y.H., Jung, C.W., Suh, M. and Jeon, M.H., 2016. Integrated construction process for green building. Procedia Engineering, 145, pp.670-676.

Bohari, A.A.M., Skitmore, M., Xia, B. and Teo, M., 2017. Green oriented procurement for building projects: Preliminary findings from Malaysia. Journal of Cleaner Production, 148, pp.690-700.

Bombugala, B. A. and Atputharajah, A., 2010. Sustainable development through green building concept in Sri Lanka. In: Proceedings of International Conference on Sustainable Built Environment (ICSBE2010), Kandy, Sri Lanka, 13-14 December 2010. pp.19-24.

Chan, A.P., Darko, A., Olanipekun, A.O. and Ameyaw, E.E., 2018. Critical barriers to green building technologies adoption in developing countries : The case of Ghana. Journal of Cleaner Production, 172, pp.1067-1079.

Chan, A.P., Yung, E.H.K., Lam, Patrick T.I., Tam, C.M., and Cheung, S.O.1., 2001. Application of delphi method in selection of procurement systems for construction projects. Construction Management and Economics, 19(7), pp.699-718.

Cheung, S., Lam, T.I., Leung, M.Y. and Wan, Y.W., 2001. An analytical hierarchy process based procurement selection method. Construction Management and Economics, 19(4), pp.427-437.

Davis, P., Love, P. and Baccarini, D., 2008. Building procurement methods, Brisbane Austrailia: Icon.Net Pty Ltd.

Hettige, N.C., Perera, B.A. and Mallawaarachchi, H., 2016. Adoptability of green lease in developing countries. In: Proceedings of the $5^{\text {th }}$ World Construction Symposium, Colombo, Sri Lanka, pp.44-52. 
Hwang, B. G. and Leong, L. P., 2013. Comparison of schedule delay and casual factors between traditional and green construction projects. Technological and Economic Development of Economy, 19(2), pp.310330.

Jefferies, M., Gameson, R. and Rowlinson, S., 2002. Critical success factors of the BOOT procurement system: reflections from the Stadium Australia case study. Engineering, Construction and Architectural Management, 9(2), pp.352-361.

Li, H., Ng, S.T. and Skitmore, M., 2018. Stakeholder impact analysis during post-occupancy evaluation of green buildings - A Chinese context. Building and Environment, 128, pp.89-95.

Liu, J.Y., Low, S.P. and He, X., 2012. Green practices in the Chinese building industry: drivers and impediments. Technology Management in China, 7(1), pp.50-63.

Love, P.E., Skitmore, M. and Earl, G., 1998. Selecting a suitable procurement method for a building project. Construction Management and Economics, 16(2), pp.221-233.

Low, S.P., Gao, S. and Tay, W.L., 2014. Comparative study of project management and critical success factors of greening new and existing buildings in Singapore. Structural Survey, 32(5), pp.413-433.

Mathonsi, M.D. and Thwala, W.D., 2012. Factors influencing the selection of procurement systems in the South African construction industry. African Journal of Business Management, 6(10), pp.3583-3594.

Oyegoke, A.S., Dickinson, M., Khalfan, M.M.A., McDermott, P. and Rowlinson, A.S., 2009. Construction project procurement routes: An in depth critique. Managing Projects in Business, 2(3), pp.338-354.

Purasinghe, R. and Maguino, E., 2010. Sustainable green building rating system for energy efficiency for new residential buildings in US. In: Proceedings of the International Conference on Sustainable Built Environment (ICSBE-2010), Kandy, Sri Lanka, 13-14 December 2010, pp.164-173.

Shiyamini, R., Rameezdeen, R. and Amaratunga, D., 2005. Macro Analysis of Construction Procurement Trend in Sri Lanka. In Proceedings of the $5^{\text {th }}$ international Postgraduate Research Conference of the Research Institute for the Built and Human Environment, University of Salford, UK (pp.525-536).

Rose, M.R., 2014. The client satisfaction of green building procurement systems, (Doctoral Dissertation) University of Witwatersrand.

Seyis, S. and Ergen, E., 2017. A decision making support tool for selecting green building certification credits based on project delivery attributes. Building and Environment, 126, pp.107-118.

Shafii, F., Ali, Z.A. and Othman, M.Z., 2006. Achieving sustainable construction in the developing countries of Southeast Asia. In: Proceedings of the $6^{\text {th }}$ Asia-Pacific Structural Engineering and Construction Conference (APSEC 2006), 5-6 September 2006, Kuala Lumpur, Malaysia (pp.29-44).

Shi, Q., Zuo, J., Huang, R., Huang, J. and Pullen, S, 2013. Identify critical factors of green construction An empirical study in china. Habitat International, 40, pp.1-8.

Stener, E., 2002. Green procurement of buildings: A study of Swedish clients' considerations. Construction Management and Economics, 20(1), pp.21-30.

Thatcher, A. and Milner, K., 2016. Is a green buildig really better for building occupant? A longitudinal evaluation. Building and Environment, 108, pp.194-206.

Vilasini, N., Neitzert, T.R. and Rotimi, J.O., 2011. Correlation between construction procurement methods and Lean principles. International Journal of Construction Management, 11(4), pp.65-78.

Waidyasekara, K.G. and Fernando, W.N., 2012. Benefits of adopting green concept for construction of buildings in Sri Lanka, In Proceedings of the $2^{\text {nd }}$ International Conference on Sustainable Built Environments, Colombo, Sri Lanka: University of Moratuwa, pp.1-13.

Wong, J.K., Chan, J.K. and Wadu, M.J., 2016. Facilitation effective green procurement in construction project: An empirical study of enablers. Journal of Cleaner Production, 135, pp.859-871.

Wu, X., Peng, B. and Lin, B., 2017. A dynamic life cycle carbon emission assessment on green and nongreen buildings in china. Energy and Building, 149, pp.272-281. 